\title{
Fruit quality in the peach and nectarine with application of hydrogenated cyanamide and mineral oil ${ }^{1}$
}

\author{
Qualidade dos frutos de pessegueiro e nectarineira com aplicação de cianamida \\ hidrogenada e óleo mineral
}

\author{
Sarita Leonel ${ }^{2 *}$, Magali Leonel ${ }^{3}$ e Marco Antonio Tecchio ${ }^{4}$
}

\begin{abstract}
This work evaluated the quality of the fruit in peach and nectarine cultivars with and without the application of hydrogenated cyanamide and mineral oil, for two production cycles (2009 and 2010). The experiment was carried out at the School of Agricultural Science of the São Paulo State University (UNESP), at Botucatu in the Brazilian state of São Paulo, located at latitude $22^{\circ} 51^{\prime} 55^{\prime \prime} \mathrm{S}$ and longitude $48^{\circ} 26^{\prime} 22^{\prime \prime} \mathrm{E}$, at an altitude of $810 \mathrm{~m}$. The predominant climate type is warm temperate (mesothermal) with rains in the summer and dry in the winter. The following were evaluated: soluble solids, titratable acidity, $\mathrm{pH}$, ratio, firmness, vitamin $\mathrm{C}$ and pulp yield. The use of hydrogenated cyanamide and mineral oil had no effect on the quality attributes of the fruit, except for $\mathrm{pH}$, where those fruits under application of the products showed higher values. The cultivars all had a pulp yield greater than $90 \%$, with 'Tourmaline' showing

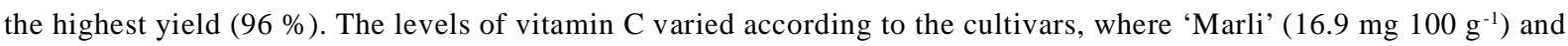
'Dourado-2' (16.5 mg $\left.100 \mathrm{~g}^{-1}\right)$, stood out for having the highest levels.
\end{abstract}

Key words: Peach. Nectarine. Hydrogenated Cyanamide. Mineral oil.

RESUMO - O trabalho avaliou a qualidade dos frutos de cultivares de pessegueiro e nectarineira, com e sem o uso de cianamida hidrogenada e óleo mineral em dois ciclos de produção (2009 e 2010). O experimento foi desenvolvido na Faculdade de Ciências Agronômicas, UNESP, câmpus de Botucatu/SP, localizado nas seguintes coordenadas geográficas: latitude $22^{\circ} 51^{\prime} 55^{\prime}$ ' S, longitude 48²6'22" O e $810 \mathrm{~m}$ de altitude. O tipo climático predominante é o temperado quente (mesotérmico) com chuvas no verão e seca no inverno. Foram avaliados: sólidos solúveis, acidez titulável, pH, "ratio", firmeza, vitamina $\mathrm{C}$ e rendimento de polpa. O emprego da cianamida hidrogenada e do óleo mineral não apresentou efeitos sobre os atributos de qualidade dos frutos, com exceção do $\mathrm{pH}$, no qual os frutos sob a aplicação dos produtos mostraram maiores valores. Todos os cultivares apresentaram rendimento de polpa acima de $90 \%$, sendo que 'Turmalina' foi o que mais se destacou por apresentar o maior rendimento de polpa (96\%). Os teores de vitamina $\mathrm{C}$ variaram de acordo com os cultivares, nos quais destacaram-se 'Marli' (16,9 mg $\left.100 \mathrm{~g}^{-1}\right)$ e 'Dourado-2' (16,5 mg $\left.100 \mathrm{~g}^{-1}\right)$, que apresentaram os maiores teores.

Palavras-chave: Pêssego. Nectarina. Cianamida Hidrogenada. Óleo mineral.

\footnotetext{
*Autor para correspondência

${ }^{1}$ Recebido para publicação em 13/09/2011; aprovado em 12/03/2014

Projeto Financiado pela FAPESP, processo $n^{\circ}$ 2009/50862-3

${ }^{2}$ Departamento de Produção Vegetal, Faculdade de Ciências Agronômicas/UNESP, Botucatu-SP, Brasil, sarinel@fca.unesp.br ${ }^{3}$ Centro de Raízes e Amidos Tropicais/UNESP, Botucatu-SP, Brasil, mleonel@ cerat.unesp.br

${ }^{4}$ Centro Avançado de Pesquisa Tecnológica do Agronegócio de Frutas, Instituto Agronômico de Campinas, Campinas-SP, Brasil, tecchio@iac. sp.gov.br
} 


\section{INTRODUCTION}

The production of peaches in the state of São Paulo has been increasing since the 1970s, with the introduction by the Agronomic Institute of Campinas of the third generation of cultivars, notably Ouromel, Dourado and Aurora, with a reduced need for cold temperatures, a flowering cycle at maturation of from 80 to 120 days and a reddish skin. At the end of 1980 the fourth generation of cultivars was launched, particularly the Douradão. Later, producers from the state of São Paulo in Brazil introduced material adapted for subtropical climates, a result of the breeding programme of the University of Florida, notably Flor da Prince, San Pedro and Tropic Beauty. In the warehouse terminal in São Paulo, the Marketing Information System [Sistema de Informação de Mercado] recorded, for the crop of 2004-05, the commercialisation of the fruit of 24 cultivars, notably of Aurora and Dourado, in fruit originating in São Paulo, and of Chimarrita and Chiripá, originating in the southern states of Brazil (ALMEIDA; DURIGAN, 2006).

The search for suitable materials is one of the first things to be done when improving the productivity of orchards (MARODIN; SANTORI; GUERRA, 2002). After that, agronomic evaluation and assessment of the quality of the fruit produced is necessary at the different locations, especially in places not having cold temperatures in the winter, as is the case of the subtropical regions (PÉREZ, 2004). Citadin et al. (2002) and Gariglio, Ortiz de Zánate e Zanuttini(2003) Gariglio et al. (2006, 2009) stress that at these locations, expansion of the crop depends upon the introduction of varieties requiring little cold, since when varieties do not have their lowtemperature needs fully met, they display inadequate vegetative and reproductive behaviour (GONZÁLEZROSSIA et al., 2007; WALTON et al., 2009).

Chemical compounds such as mineral oil, dinitroortho-cresol, thiourea, potassium nitrate, calcium nitrate, gibberellic acid and cytokinins are said to be effective in breaking the dormancy of many fruit trees, being able partially to replace the need for cold and to stimulate the early and uniform opening of buds. The greater efficiency of calcium cyanamide $\left(\mathrm{CaCN}_{2}\right)$ and hydrogenated cyanamide (H2CN2), stems from the presence of the radical $-\mathrm{C} \equiv \mathrm{N}$, which is more reactive (OR; VIOZNY; FENNEL, 2002; PEREZ; LIRA, 2005; PIRES; MARTINS, 2003). This product, acting as a stimulus in breaking dormancy in the buds, has been responsible for the advancement of temperate fruit trees into subtropical regions. There is a need to study the effects of these compounds in the peach with reference to the region, since most references are to traditional growing regions having a temperate climate. Added to this, those works deal with the effect on standardisation and increased production, but there are no reports on the quality of the fruit being produced (BOUND;
JONES, 2004), since this product has seen usage restrictions in international markets due to being considered toxic.

In this context, the present work aimed to assess the quality of fruit in the peach and nectarine under the application of hydrogenated cyanamide and mineral oil, in a subtropical region, in Botucatu, in the state of São Paulo, Brazil.

\section{MATERIAL AND METHODS}

The study was carried out on the Lageado Experimental Farm of the Faculty for Agricultural Sciences at the São Paulo State University (UNESP), located at $22^{\circ} 51^{\prime} 55^{\prime \prime} \mathrm{S}$ and $48^{\circ} 26^{\prime} 22^{\prime \prime} \mathrm{W}$, at an altitude of $810 \mathrm{~m}$. The climate is mesothermal, classified as Cwa, subtropical humid. The average rainfall is 1,433 $\mathrm{mm}$. Relative humidity is $71 \%$, with an average annual temperature of $19.3{ }^{\circ} \mathrm{C}$ (CUNHA, 1999). The soil in the area is classified as Red Nitosol.

The experimental design was of split lots, with three replications of randomised blocks, with the lots consisting of treatments both with and without the application of hydrogenated cyanamide and mineral oil, and the sublots of various peach and nectarine cultivars. Four plants were used per lot, which were surrounded by border plants. The peach cultivars Aurora 1, Tropic Beauty, Douradão, Dourado 2 and Marli were evaluated, together with the nectarine cultivar Sun Blaze, all traditionally grown in São Paulo; the Turmalina and Precocinho cultivars grown in Rio Grande do Sul; and some opportunities for diversification such as selections from Cascata (953, 797 and 587) and Conserva 693 from Rio Grande do Sul, and Diamante Mejorado, CP 9553 CYN and CP 951 C from Mexico.

The experiment took place during the agricultural cycles of 2009 and 2010. The plants were 5 years old and grown at a spacing of $4.0 \mathrm{~m}$ between rows and $4.0 \mathrm{~m}$ between plants. During the experiment, both phytosanitary and cultivation practices were carried out following the technical recommendations for the crop. Fruits were pruned in the first week of July (2009 and 2010), with thinning being carried out two weeks after full bloom. Hydrogenated cyanamide was used on two plants per replication for each cultivar, at a dosage of $0.6 \%$ with $1 \%$ mineral oil. The solution was applied in the second week of July (2009 and 2010) in the dormantbud stage, by spraying, with the use of a plastic curtain so as to avoid product drift. The harvest was held when the fruits reached the point of physiological maturity, from the end of September until mid-December.

Thirty fruits from each cultivar were evaluated. These underwent physicochemical analyses of: pulp firmness (measured in whole fruits with peel at 3 points, using a Stevens LFRA texturometer, and determined by the pressure 
in Newtons $(\mathrm{N})$ needed for a test probe of $6 \mathrm{~mm}$ in diameter to penetrate $20 \mathrm{~mm}$ into the fruit); soluble solids; $\mathrm{pH}$; titratable acidity (INSTITUTO ADOLFO LUTZ, 1985); acid ratio (SS/TA); vitamin C (TERADA et al., 1979); and yield, (obtained by the ratio of whole fruit (peel, pulp and seed) to pulp). The results were subjected to variance analysis and when significant, the means were compared by Tukey test at 1 and $5 \%$.

\section{RESULTS AND DISCUSSION}

For the attributes of fruit quality, breakdown of the interaction between the use of hydrogenated cyanamide and mineral oil and the cultivar being evaluated was not significant for the two evaluation cycles (Table 1 and 2). For the factor, hydrogenated cyanamide, there were differences in $\mathrm{pH}$ and acidity for the 2009 cycle (Table 3 ). For the 2010 cycle, there was a difference in $\mathrm{pH}$ and vitamin $\mathrm{C}$ (Table 4). There were differences between cultivars for the 2009 cycle in soluble solids, pH, pulp yield and firmness (Table 5). For the 2010 cycle, there was a difference for the same variable in soluble solid content, vitamin $\mathrm{C}$ and firmness (Table 6).
For pulp yield, there were differences between the cultivars, with Turmalina $(97.8 \%)$ and Conserva 693 $(97.0 \%)$ differing from Tropic Beauty (91.9\%) and Cascata 587 (91.0\%), by having the highest yield for the 2009 cycle (Table 3). Turmalina also presented the highest yield $(94.5 \%)$ for the 2010 cycle. In general, it is possible to consider that all the cultivars presented good pulp yields of over $90 \%$ (Tables 3 and 4). Some authors report that the presence of loose and semi-loose pits and firm flesh are requirements for good yields (RASEIRA; HAKATA, 1998). According to Trevisan et al. (2006), consumers of fresh peaches in Pelotas in the state of Rio Grande do Sul, prefer fruit of a large size, with a predominance of red skin colouring, a good yield of yellow pulp and a sweet flavour. With the exception of the Cascata 587 selection and the Marli cultivar, which have white flesh, all the tested genotypes have a yellow pulp, making viable their use in industry. Nakasu and Raseira (1999) have already shown that the Turmalina cultivar can be dual purpose, i.e. for fresh consumption as well as for industrialisation, in the form of jam.

Table 1 - Results of the F-test of variance analysis for soluble solids (SS), pH, titratable acidity (TA), acid ratio (SS/TA), vitamin $\mathrm{C}$, yield and fruit firmness in the peach and nectarine, with and without the application of hydrogenated cyanamide (HC) and mineral oil (MO). Botucatu

\begin{tabular}{lccccccc}
\hline FV & SS & pH & Acidity & Ratio & Vit. C & Yield & Texture \\
\hline HC + MO & $0.37^{\mathrm{NS}}$ & $78.74^{* *}$ & $8.23^{*}$ & $0.52^{\mathrm{NS}}$ & $0.01^{\mathrm{NS}}$ & $3.35^{\mathrm{NS}}$ & $0.55^{\mathrm{NS}}$ \\
Cultivars (C) & $22.92^{* *}$ & $2.37^{*}$ & $18.70^{* *}$ & $16.46^{* *}$ & $10.74^{* *}$ & $8.44^{* *}$ & $39.45^{* *}$ \\
HC + MO x C & $1.48^{\mathrm{NS}}$ & $0.83^{\mathrm{NS}}$ & $2.05^{*}$ & $2.38^{*}$ & $3.51^{* *}$ & $0.74^{\mathrm{NS}}$ & $0.77^{\mathrm{NS}}$ \\
CV 1 (\%) & 2.38 & 3.08 & 7.6 & 19.28 & 9.15 & 0.8 & 9.84 \\
CV 2 (\%) & 4.9 & 12.49 & 15.21 & 23.05 & 12.27 & 1.85 & 8.28 \\
Average & 11.79 & 3.69 & 0.64 & 21.04 & 12.99 & 94.41 & 248.39 \\
\hline
\end{tabular}

* significant at $5 \% ; * *$ significant at $1 \%$ Tukey test; ns - not significant

Table 2 - Results of the F-test of variance analysis for soluble solids (SS), pH, titratable acidity (TA), acid ratio (SS/TA), vitamin $\mathrm{C}$, yield and fruit firmness in the peach and nectarine, with and without the application of hydrogenated cyanamide (HC) and mineral oil (MO). Botucatu

\begin{tabular}{lccccccc}
\hline FV & SS & $\mathrm{pH}$ & Acidity & Ratio & Vit. C & Yield & Firmness \\
\hline $\mathrm{HC}+\mathrm{MO}$ & $1.3^{\mathrm{NS}}$ & $5.8^{*}$ & $0.5^{\mathrm{NS}}$ & $0.9^{\mathrm{NS}}$ & $20.0^{* *}$ & $2.1^{\mathrm{NS}}$ & $0.1^{\mathrm{NS}}$ \\
Cultivars (C) & $3.6^{* *}$ & $1.1^{\mathrm{NS}}$ & $1.3^{\mathrm{NS}}$ & $2.2^{\mathrm{NS}}$ & $17.2^{* *}$ & $0.8^{\mathrm{NS}}$ & $16.7^{* *}$ \\
$\mathrm{HC}+\mathrm{MO} \times \mathrm{C}$ & $0.6^{\mathrm{NS}}$ & $0.8^{\mathrm{NS}}$ & $1.0^{\mathrm{NS}}$ & $1.1^{\mathrm{NS}}$ & $1.3^{\mathrm{NS}}$ & $1.1^{\mathrm{NS}}$ & $0.8^{\mathrm{NS}}$ \\
CV 1 (\%) & 10.2 & 24.2 & 19.6 & 23.9 & 7.9 & 4.2 & 11.5 \\
CV 2 (\%) & 9.3 & 22.8 & 19.8 & 26.2 & 10.5 & 4.4 & 12.5 \\
Average & 12 & 3.6 & 0.8 & 16.1 & 12.7 & 92.5 & 252.9 \\
\hline
\end{tabular}

* significant at $5 \%$;* significant at $1 \%$ Tukey test; ns - not significant 
Table 3 - Average results for soluble solids (SS), pH, titratable acidity (TA), acid ratio (SS/TA), vitamin C, yield and fruit firmness in the peach and nectarine, with and without the application of hydrogenated cyanamide (HC) and mineral oil (MO). FCA/UNESP/Botucatu

\begin{tabular}{|c|c|c|c|c|c|c|c|}
\hline \multirow{2}{*}{$\mathrm{HC}+\mathrm{MO}$} & SS & \multirow{2}{*}{$\mathrm{pH}$} & Acidity & \multirow{2}{*}{ Ratio } & Vit. C & Pulp Yield & Firmness \\
\hline & $\left({ }^{\circ} \mathrm{Brix}\right)$ & & (g citric acid $100 \mathrm{~g}$ pulp) & & $\left(\mathrm{mg} 100 \mathrm{~g}^{-1}\right)$ & $(\%)$ & $(\mathrm{N})$ \\
\hline With & $11.8 \mathrm{a}$ & $3.79 \mathrm{a}$ & $0.65 \mathrm{a}$ & $20.7 \mathrm{a}$ & $13.0 \mathrm{a}$ & $94.3 \mathrm{a}$ & $24.65 \mathrm{a}$ \\
\hline Without & $11.8 \mathrm{a}$ & $3.58 \mathrm{~b}$ & $0.62 \mathrm{~b}$ & $21.3 \mathrm{a}$ & $13.0 \mathrm{a}$ & $94.6 \mathrm{a}$ & $25.03 \mathrm{a}$ \\
\hline
\end{tabular}

Averages followed by the same letter in a column do not differ by Tukey test at $1 \%$

Table 4 - Average results for soluble solids (SS), pH, titratable acidity (TA), acid ratio (SS/TA), vitamin C, yield and fruit firmness in the peach and nectarine, with and without the application of hydrogenated cyanamide (HC) and mineral oil (MO). FCA/UNESP/Botucatu

\begin{tabular}{|c|c|c|c|c|c|c|c|}
\hline \multirow{2}{*}{$\mathrm{HC}+\mathrm{MO}$} & SS & \multirow{2}{*}{$\mathrm{pH}$} & Acidity & \multirow{2}{*}{ Ratio } & Vit. C & Pulp Yield & Firmness \\
\hline & $\left({ }^{\circ} \mathrm{Brix}\right)$ & & (g/100g pulp) & & $\left(\mathrm{mg} \mathrm{L}^{-1}\right)$ & $(\%)$ & $(\mathrm{N})$ \\
\hline With & $12.2 \mathrm{a}$ & $3.87 \mathrm{a}$ & $0.80 \mathrm{a}$ & $16.4 \mathrm{a}$ & $13.2 \mathrm{a}$ & $93.0 \mathrm{a}$ & $25.40 \mathrm{a}$ \\
\hline Without & $11.9 \mathrm{a}$ & $3.42 \mathrm{~b}$ & $0.77 \mathrm{a}$ & $15.7 \mathrm{a}$ & $12.2 \mathrm{~b}$ & $91.9 \mathrm{a}$ & $25.10 \mathrm{a}$ \\
\hline Average & 12 & 3.65 & 0.79 & 16.1 & 12.7 & 92.5 & 25.25 \\
\hline
\end{tabular}

Averages followed by the same letter in a column do not differ by Tukey test at $5 \%$

Table 5 - Average results for soluble solids (SS), pH, titratable acidity (TA), acid ratio (SS/TA), vitamin C, yield and fruit texture in the peach and nectarine, with and without the application of hydrogenated cyanamide and mineral oil. FCA/UNESP/Botucatu

\begin{tabular}{|c|c|c|c|c|c|c|c|}
\hline \multirow{2}{*}{ Cultivar } & SS & \multirow{2}{*}{$\mathrm{pH}$} & \multirow{2}{*}{$\frac{\text { Acidity }}{\text { (g/100g pulp) }}$} & \multirow{2}{*}{ Ratio } & \multirow{2}{*}{$\frac{\text { Vit. C }}{\left(\mathrm{mg} \mathrm{L}^{-1}\right)}$} & \multirow{2}{*}{$\frac{\text { Pulp Yield }}{(\%)}$} & \multirow{2}{*}{$\frac{\text { Firmness }}{(\mathrm{N})}$} \\
\hline & ( ${ }^{\circ}$ Brix $)$ & & & & & & \\
\hline Turmalina & $11.6 \mathrm{~b}$ & $3.27 \mathrm{~b}$ & $0.67 \mathrm{a}$ & $17.6 \mathrm{a}$ & $9.9 \mathrm{a}$ & $97.8 \mathrm{a}$ & $27.26 \mathrm{ab}$ \\
\hline Cascata 953 & $11.5 \mathrm{~b}$ & $3.22 \mathrm{~b}$ & $0.79 \mathrm{a}$ & $14.7 \mathrm{a}$ & $10.8 \mathrm{a}$ & $92.9 \mathrm{ab}$ & $29.43 \mathrm{a}$ \\
\hline Cascata 797 & $12.8 \mathrm{a}$ & $3.95 \mathrm{a}$ & $0.77 \mathrm{a}$ & $17.1 \mathrm{a}$ & $11.8 \mathrm{a}$ & $96.2 \mathrm{ab}$ & $27.04 \mathrm{a}$ \\
\hline Cascata 587 & $12.5 \mathrm{ab}$ & $4.05 \mathrm{a}$ & $0.55 \mathrm{a}$ & $23.4 \mathrm{a}$ & $12.5 \mathrm{a}$ & $91.0 \mathrm{~b}$ & $21.46 \mathrm{bc}$ \\
\hline Conserva 693 & $12.4 \mathrm{ab}$ & $3.60 \mathrm{a}$ & $0.78 \mathrm{a}$ & $16.0 \mathrm{a}$ & $13.3 \mathrm{a}$ & $97.0 \mathrm{a}$ & $29.90 \mathrm{a}$ \\
\hline Precocinho & $11.5 \mathrm{~b}$ & $3.58 \mathrm{a}$ & $0.60 \mathrm{a}$ & $19.3 \mathrm{a}$ & $12.7 \mathrm{a}$ & $93.0 \mathrm{ab}$ & $22.01 \mathrm{bc}$ \\
\hline Diamante Mejorado & $11.4 \mathrm{~b}$ & $3.72 \mathrm{a}$ & $0.82 \mathrm{a}$ & $13.9 \mathrm{a}$ & $14.4 \mathrm{a}$ & $95.9 \mathrm{ab}$ & $28.85 \mathrm{a}$ \\
\hline Aurora 1 & $11.9 \mathrm{ab}$ & $3.70 \mathrm{a}$ & $0.48 \mathrm{a}$ & $25.0 \mathrm{a}$ & $11.4 \mathrm{a}$ & $94.5 \mathrm{ab}$ & $22.25 \mathrm{bc}$ \\
\hline CP 9553 CYN & $11.4 \mathrm{~b}$ & $3.47 \mathrm{ab}$ & $0.72 \mathrm{a}$ & $16.1 \mathrm{a}$ & $11.9 \mathrm{a}$ & $95.5 \mathrm{ab}$ & $25.92 \mathrm{ab}$ \\
\hline Tropic Beauty & $12.2 \mathrm{c}$ & $3.53 \mathrm{a}$ & $0.81 \mathrm{a}$ & $14.4 \mathrm{a}$ & $10.0 \mathrm{a}$ & $91.9 \mathrm{~b}$ & $25.99 \mathrm{a}$ \\
\hline Douradão & $12.8 \mathrm{ab}$ & $3.95 \mathrm{ab}$ & $0.86 \mathrm{a}$ & $34.3 \mathrm{a}$ & $15.2 \mathrm{a}$ & $95.8 \mathrm{ab}$ & $28.58 \mathrm{a}$ \\
\hline Dourado 2 & $12.8 \mathrm{ab}$ & $4.11 \mathrm{a}$ & $0.40 \mathrm{a}$ & $33.9 \mathrm{a}$ & $16.3 \mathrm{a}$ & $93.4 \mathrm{ab}$ & $18.00 \mathrm{c}$ \\
\hline Marli & $12.3 \mathrm{ab}$ & $4.11 \mathrm{a}$ & $0.42 \mathrm{a}$ & $35.0 \mathrm{a}$ & $16.4 \mathrm{a}$ & $93.3 \mathrm{ab}$ & $10.66 \mathrm{c}$ \\
\hline Sun Blaze & $11.6 \mathrm{ab}$ & $3.46 \mathrm{a}$ & $0.37 \mathrm{a}$ & $24.0 \mathrm{a}$ & $15.1 \mathrm{a}$ & $91.9 \mathrm{ab}$ & $24.85 \mathrm{ab}$ \\
\hline СР 951-C & $8.2 \mathrm{ab}$ & $3.61 \mathrm{ab}$ & $0.52 \mathrm{a}$ & $10.2 \mathrm{a}$ & $13.2 \mathrm{a}$ & $96.1 \mathrm{ab}$ & $26.79 a b$ \\
\hline Average & 11.8 & 3.41 & 0.64 & 21.04 & 13 & 94.4 & 24.6 \\
\hline
\end{tabular}

Averages followed by different letters differ by Tukey test at $1 \%$ 
Table 6 - Average results for soluble solids (SS), pH, titratable acidity (TA), acid ratio (SS/TA), vitamin C, yield and fruit firmness in the peach and nectarine, with and without the application of hydrogenated cyanamide and mineral oil. FCA/UNESP/Botucatu

\begin{tabular}{|c|c|c|c|c|c|c|c|}
\hline \multirow{2}{*}{ Cultivar } & SS & \multirow{2}{*}{$\mathrm{pH}$} & Acidity & \multirow{2}{*}{ Ratio } & Vit. C & Pulp Yield & Firmness \\
\hline & $\left({ }^{\circ} \mathrm{Brix}\right)$ & & (g /100g pulp) & & $\left(\mathrm{mg} \mathrm{L}^{-1}\right)$ & $(\%)$ & $(\mathrm{N})$ \\
\hline Turmalina & $12.6 \mathrm{ab}$ & $3.50 \mathrm{a}$ & $0.77 \mathrm{a}$ & $17.9 \mathrm{a}$ & $9.2 \mathrm{f}$ & $94.5 \mathrm{a}$ & $27.68 \mathrm{abc}$ \\
\hline Cascat 953 & $12.0 \mathrm{ab}$ & $3.22 \mathrm{a}$ & $0.85 \mathrm{a}$ & $14.4 \mathrm{a}$ & $10.3 \mathrm{ef}$ & $92.7 \mathrm{a}$ & $27.22 \mathrm{abc}$ \\
\hline Cascata 797 & $12.7 \mathrm{ab}$ & $3.98 \mathrm{a}$ & $0.90 \mathrm{a}$ & $14.2 \mathrm{a}$ & $14.3 \mathrm{bc}$ & $93.1 \mathrm{a}$ & 25.00 bcde \\
\hline Cascata 587 & $12.4 \mathrm{ab}$ & $3.73 \mathrm{a}$ & $0.75 \mathrm{a}$ & $17.0 \mathrm{a}$ & $13.4 \mathrm{~cd}$ & $89.4 \mathrm{a}$ & $20.61 \mathrm{de}$ \\
\hline Conserva 693 & $12.9 \mathrm{ab}$ & $3.43 \mathrm{a}$ & $0.78 \mathrm{a}$ & $16.9 \mathrm{a}$ & $13.3 \mathrm{~cd}$ & $94.7 \mathrm{a}$ & $33.11 \mathrm{a}$ \\
\hline Precocinho & $11.4 \mathrm{ab}$ & $3.40 \mathrm{a}$ & $0.77 \mathrm{a}$ & $14.9 \mathrm{a}$ & $11.8 \mathrm{cdef}$ & $92.3 \mathrm{a}$ & $22.54 \mathrm{cde}$ \\
\hline Diamante Mejorado & $11.3 \mathrm{ab}$ & $3.38 \mathrm{a}$ & $0.79 \mathrm{a}$ & $15.0 \mathrm{a}$ & $11.8 \mathrm{cdef}$ & $93.6 \mathrm{a}$ & $30.56 \mathrm{ab}$ \\
\hline Aurora 1 & $12.1 \mathrm{ab}$ & $3.58 \mathrm{a}$ & $0.78 \mathrm{a}$ & $15.9 \mathrm{a}$ & $11.9 \mathrm{cdef}$ & $92.2 \mathrm{a}$ & $22.79 \mathrm{cde}$ \\
\hline CP 9553 CYN & $11.3 \mathrm{ab}$ & $3.57 \mathrm{a}$ & $0.90 \mathrm{a}$ & $12.5 \mathrm{a}$ & $12.7 \mathrm{cde}$ & $93.0 \mathrm{a}$ & $27.28 \mathrm{abcd}$ \\
\hline Tropic Beauty & $11.0 \mathrm{ab}$ & $3.55 \mathrm{a}$ & $0.82 \mathrm{a}$ & $14.0 \mathrm{a}$ & $10.8 \mathrm{def}$ & $92.2 \mathrm{a}$ & $31.31 \mathrm{ab}$ \\
\hline Douradão & $13.2 \mathrm{a}$ & $4.37 \mathrm{a}$ & $0.67 \mathrm{a}$ & $20.7 \mathrm{a}$ & $11.2 \mathrm{def}$ & $93.0 \mathrm{a}$ & $28.84 \mathrm{abc}$ \\
\hline Dourado 2 & $13.0 \mathrm{ab}$ & $4.20 \mathrm{a}$ & $0.65 \mathrm{a}$ & $21.4 \mathrm{a}$ & $16.7 \mathrm{ab}$ & $90.7 \mathrm{a}$ & $19.04 \mathrm{ef}$ \\
\hline Marli & $12.8 \mathrm{ab}$ & $4.05 \mathrm{a}$ & $0.77 \mathrm{a}$ & $17.5 \mathrm{a}$ & $17.4 \mathrm{a}$ & $92.9 \mathrm{a}$ & $12.78 \mathrm{f}$ \\
\hline Sun Blaze & $11.2 \mathrm{ab}$ & $3.18 \mathrm{a}$ & $0.75 \mathrm{a}$ & $15.7 \mathrm{a}$ & $11.9 \mathrm{cdef}$ & $90.1 \mathrm{a}$ & $23.13 \mathrm{cde}$ \\
\hline CP 951-C & $10.7 \mathrm{~b}$ & $3.55 \mathrm{a}$ & $0.85 \mathrm{a}$ & $13.1 \mathrm{a}$ & $13.5 \mathrm{~cd}$ & $92.4 \mathrm{a}$ & $26.89 \mathrm{abcd}$ \\
\hline Average & 12.0 & 3.65 & 0.79 & 16.1 & 12.7 & 92.5 & 25.25 \\
\hline
\end{tabular}

Médias seguidas de letras diferentes se diferem entre si pelo teste Tukey ao nível de 5\%

For firmness of pulp, there were variations between cultivars for the 2009 cycle, notably Conserva $693(29.90 \mathrm{~N})$, Tropic Beauty $(29.59 \mathrm{~N})$ and the Cascata 953 selection $(29.43 \mathrm{~N})$ which differed from the cultivars, Aurora-1 $(22.25 \mathrm{~N})$, Precocinho $(22.01 \mathrm{~N})$ and Cascata $587(21.46 \mathrm{~N})$, by having fruit with firmer pulp. For the 2010 cycle, there were variations between the cultivars (Table 4), especially the Marli cultivar which had the lowest firmness of pulp $(12.78 \mathrm{~N})$. The Conserva 693 cultivar showed the greatest firmness (33.11 N) when compared to Cascata 587, Precocinho, Aurora 1, Dourado 2 and Marli. Firm pulp is considered an important and favourable characteristic when the intention is the industrial use of the fruit, as is the case with this cultivar. According Toebe et al. (2011), firmness of the pulp, and skin colour, are the main attributes used when evaluating quality and ripeness in the fruit. According to Chitarra and Chitarra (2005), firmer fruits are more resistant to shocks and damage during transportation. Marodin, Santori and Guerra (2002) found fruits of Aurora-2 with a firmness of $56 \mathrm{~N}$, and fruits of Diamante Mejorado of $35.6 \mathrm{~N}$, both when ready for harvest, which demonstrates the great variability of peach genotypes with respect to this variable.

Flavour is a result of the sensitivity of the tongue in discerning sensations of sweet and sour produced by the concentration of sugars and organic acids and by the ratio between these values; the higher this ratio, the greater the sensation of sweetness perceived by the tongue. The physical and chemical characteristics revealed by the levels of soluble solids, the $\mathrm{pH}$, titratable acidity, maturation index (acid ratio) and vitamin $\mathrm{C}$, among others, are indicators of those sensory characteristics which are important to the consumer and to industry (CHITARRA; CHITARRA, 2005).

When evaluating cultivars from the 2010 cycle, there were variations in the levels of soluble solids from 13.2 to $10.7^{\circ}$ Brix. In 2009 , the cultivar CP $951 \mathrm{C}$ (8.2 ${ }^{\circ}$ Brix) differed from the others by having the lowest value. Raseira and Nakasu (1998) concluded that the levels of SS for Precocinho and Turmalina were 8-11 ${ }^{\circ}$ Brix and $10-13{ }^{\circ}$ Brix respectively, values close to those found in this work, where Precocinho presented on average 11.5 ${ }^{\circ}$ Brix (2009) and $11.4^{\circ}$ Brix (2010), and Turmalina, $11.6^{\circ}$ Brix (2009) and $12.6^{\circ}$ Brix (2010), falling within the range which characterises these cultivars, even with the tests having been carried out at different times and places.

In relation to the Cascata selections, Raseira et al. (2007) reported levels of soluble solids in the range 11-16 ${ }^{\circ}$ Brix. In the 2009 cycle the Cascata 953 selection had a value of $11.5^{\circ}$ Brix, Cascata 797 of $12.8^{\circ}$ Brix and 
Cascata 587 of $12.5^{\circ}$ Brix. In the 2010 evaluation the values were respectively: $12.0{ }^{\circ}$ Brix (Cascata 953); 12.7 ${ }^{\circ}$ Brix (Cascata 797); and $12.4^{\circ}$ Brix (Cascata 587). The levels of soluble solids presented by the selections are very close, allowing no selection to be chosen based on that variable.

In the same way as seen for the Cascata selections, Tropic Beauty showed little variation in levels of soluble solids, being respectively $12.2^{\circ}$ Brix in 2009 and $11.0^{\circ}$ Brix in 2010 . According to Almeida and Durigan (2006) this cultivar, the result of a breeding program of the University of Florida (USA), is one of the earliest to be commercialised in the Sao Paulo Warehouse Terminal of CEAGESP where it was marketed in the 2005/2006 season with average levels of $8.5{ }^{\circ}$ Brix, $0.7 \mathrm{~g}$ citric acid $100 \mathrm{ml}^{-1}$ titratable acidity and an acid ratio of 12.9 , showing that the fruits were marketed with a low rate of maturation, since fruits which are harvested for medium-term commercialisation are picked in the early stages of ripening. As for the cultivars, Douradão, Aurora and Dourado, in that same study the authors found values of: Douradão $\left(8.9^{\circ} \mathrm{Brix}, 0.4 \mathrm{~g}\right.$ citric acid $100 \mathrm{ml}^{-1}$ titratable acidity and an acid ratio of 34.6); Aurora $\left(8.7{ }^{\circ}\right.$ Brix, $0.5 \mathrm{~g}$ citric acid $100 \mathrm{ml}^{-1}$ titratable acidity and an acid ratio of 17.5 ); Dourado (9.6 ${ }^{\circ}$ Brix, $0.4 \mathrm{~g}$ citric acid $100 \mathrm{ml}^{-1}$ titratable acidity and an acid ratio of 23.6). The cultivars, Douradão and Tropic Beauty, and the series, Dourado and Aurora, represented 89\% of the marketed volume.

Marodin, Pereira Dias and Castro (2008), when evaluating the Mexican cultivars, Oro Azteca, Diamante Especial, Diamante Mejorado, Oro B and Oro C, and the CP-C selections in Eldorado do Sul, in the state of Rio Grande do Sul, found values for titratable acidity of from 0.593 to $0.847 \mathrm{~g}$ citric acid $100 \mathrm{~g}$, with the cultivars being considered acidic. However, due to presenting a level of SS of over $10^{\circ}$ Brix, the ratio SS/AT (acid ratio) was considered as being adequate. According to Chitarra and Chitarra (2005), the minimum soluble-solid content for peach consumption is $10^{\circ} \mathrm{Brix}$, and the maximum titratable acidity is $0.60 \mathrm{~g}$ citric acid $/ 100 \mathrm{~g}$ pulp. The ratio of soluble solids to titratable acidity (acid ratio) indicates the rate of maturation of the fruit. In 2009, the highest values were observed for the cultivars Marli (35.0), Douradão (34.3) and Dourado-2 (33.9). In 2010 , there was no difference in relation to the use of hydrogenated cyanamide (16.4) or not (15.7), nor in relation to the cultivars which were evaluated. According to Costa et al. (2008) the ratio of soluble solids to titratable acidity (acid ratio) is an indicator of the maturation level of the fresh fruit. In general this ratio in the peach can vary from 16.5 to 36.0 , with a value of 25 or above representing the optimal maturity for consumption. In the present work, the values of the SS/TA ratio ranged from 12.5 (CP 9553-CYN) and 21.4 (Dourado 2).
A variation in $\mathrm{pH}$ was seen between the use of hydrogenated cyanamide (3.79) and the control (3.58), and also among the cultivars being evaluated: there being few differences among cultivars for this last variable, ranging from 4.11 (Dourado-2 and Marli) to 3.22 (Cascata 953) in 2009. In 2010 there was also a variation in relation to the use (3.87) or not (3.42) of hydrogenated cyanamide. Among the cultivars, the values ranged from 3.18 (the Sun Blaze nectarine) and 4.37 (the Douradão peach). Chitarra and Chitarra (2005) concluded that $\mathrm{pH}$ in the peach can vary from 3.5 to 4.8. According to Barbosa et al. (1997), the $\mathrm{pH}$ varied between 4.0 and 4.5 for peach cultivars and 3.6 and 4.5 for nectarine cultivars. The Sun Blaze nectarine evaluated in this trial presented $\mathrm{pH}$ values of 3.46 in 2009 and 3.16 in 2010. The results obtained in the two evaluation cycles of the experiment are evidence of the increase in the $\mathrm{pH}$ of fruit from the use of hydrogenated cyanamide and mineral oil. This fact, despite there being almost no references of the effects of these products on fruit quality, indicate and confirm the reactive and acid nature of the product (GEORGE; NISSEN, 1993; MIZOBUTSI et al., 2003). Similarly to that observed for $\mathrm{pH}$, there were differences from the use of hydrogenated cyanamide on titratable acidity in 2009, with fruits that received the treatment being more acidic $\left(0.65 \mathrm{~g}\right.$ citric acid $\left.100 \mathrm{~g} \mathrm{pulp}^{-1}\right)$ compared to the control

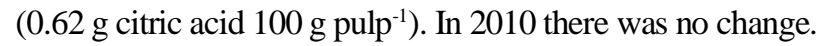

In 2009, the vitamin C content varied with cultivar. For this variable the cultivars with the highest concentrations were Marli (16.4 mg $100 \mathrm{~g}^{-1}$ ) and Dourado-2 (16.3 mg $100 \mathrm{~g}^{-1}$ ); Marli having white pulp and Dourado-2 yellow pulp. Likewise, for the 2010 cycle, the cultivars, Marli (17.4 mg $100 \mathrm{~g}^{-1}$ ) and Dourado-2 (16.7 mg $\left.100 \mathrm{~g}-1\right)$ showed the highest values, leading to the conclusion that for the peaches under test, the colour of the pulp did not interfere in the levels of vitamin C. According to Gil et al. (2002), vitamin $C$ values ranged from 5.2 to $7.1 \mathrm{mg}^{100 \mathrm{~g}^{-1}}$

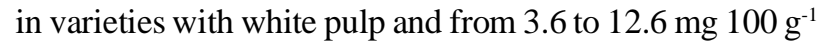
for cultivars with yellow pulp.

\section{CONCLUSIONS}

1. The use of hydrogenated cyanamide and mineral oil, needed to standardise and anticipate budding in the peach and nectarine when grown in subtropical regions, had no effect on the quality attributes of the fruit, with the exception of $\mathrm{pH}$, in which the fruit under application of these products presented higher values for the two evaluation cycles;

2. The cultivars when assessed all showed pulp yields of over $90 \%$. The levels of vitamin $\mathrm{C}$ varied according to 
cultivar, with Marli (16.9 mg $100 \mathrm{~g}^{-1}$ ) and Dourado-2 $\left(16.5 \mathrm{mg} 100 \mathrm{~g}^{-1}\right)$, standing out with the highest levels.

\section{REFERENCES}

ALMEIDA, G.B. V.; DURIGAN, J.F. Relação entre as características químicas e o valor dos pêssegos comercializados pelo sistema veiling frutas Holambra em Paranapanema-SP. Revista Brasileira de Fruticultura, v. 28, n. 2, p. 218-221, 2006.

BARBOSA, W. et al. Avaliação de pessegueiros e nectarineiras introduzidas no Brasil, procedentes da Flórida, EUA. Scientia Agrícola, v. 54, n. 3, p. 152-159, 1997.

BOUND, S. A.; JONES, K. M. Hydrogen cyanamide impacts of flowering, crop load, and fruit quality of red 'Fuji' apple (Malus domestica). New Zealand Journal of Crop and Horticultural Science, v. 32, n. 2, p. 227-234, 2004.

CHITARRA M. I. F.; CHITARRA A. B. Pós-colheita de frutos e hortaliças - Fisiologia e Manuseio. Lavras: UFLA, 2005. 785 p.

CITADIN, I. et al. Avaliação da necessidade de frio em pessegueiro. Revista Brasileira de Fruticultura, v. 24, n. 3, p. 703-706, 2002.

COSTA, S. M. et al. Conservação frigorificada de pêssegos 'Tropic Beauty' irradiados. Revista Iberoamericana de Tecnologia Postcosecha, v. 9, n. 2, p. 131-137, 2008.

CUNHA, A. R. et al. Classificação climática para o município de Botucatu-SP, segundo Koppen. In: SIMPÓSIO EM ENERGIA NA AGRICULTURA, 1., 1999, Botucatu. Anais... Botucatu: Faculdade de Ciências Agronômicas, Universidade Estadual Paulista, 1999. p. 487-491.

GARIGLIO, N. F.; ORTIZ DE ZÁRATE, V. G.; ZANUTTINI, A. M. Comportamineto reproductivo de 13 variedades de duraznero (Prunus persica L. Batsch) cultivados em La zona centro-oeste de La província de santa Fé. Horticultura Argentina, v 20, n. 22, p. 54, 2003.

GARIGLIO, N. F. et al. Effect of artificial chilling on the depth of endodormancy and leaf and flower budbreak of peach and nectarine cultivars using excised shoots. Scientia Horticulturae, v. 108, n. 4, p. 371-377, 2006.

GARIGLIO, N. F. et al. Phenology and reproductive traits of peaches and nectarines in central-east Argentina. Ciência Agrícola, v. 66, n. 6, p. 757-763, 2009.

GEORGE, A. P.; NISSEN, R. J. Effects of growth regulators on defoliation, flowering, and fruit maturity of the low chill peach cultivar Flordaprince in subtropical Australia. Australian Journal of Experimental Agriculture, v. 33, p. 787-795, 1993.

GIL, M.I. et al. Antioxidant Capacities, Phenolic Compounds, Carotenoids, and Vitamin C Contents of Nectarine, Peach, and Plum Cultivars from California. Journal of Agricultural and Food Chemistry, v.50, n.17, p. 4976-4982, 2002.

GONZÁLEZ-ROSSIA, D. et al. Horticultural factors regulating effectiveness of $\mathrm{GA}_{3}$ inhibiting flowering in peaches and nectarines (Prunus persica L. Batsch). Scientia Horticulturae, v. 111, n. 4, p. 352-357, 2007.
INSTITUTO ADOLFO LUTZ. Métodos físicos e químicos para análise de alimentos. 3. ed. São Paulo, 1985. 533 p.

MARODIN, G. A. B.; SARTORI, I. A.; GUERRA, D. S. Efeito da aplicação de cianamida hidrogenada e óleo mineral na quebra de dormência e produção do pessegueiro 'Flamecrest'. Revista Brasileira de Fruticultura, v. 24, n. 2, p. 426-430, 2002.

MARODIN, G. A. B.; PEREIRA DIAS, F.; CASTRO, B. Comportamento de algumas cultivares de pêssegos na depressão central do Rio Grande do Sul In: CONGRESSO BRASILEIRO DE FRUTICULTURA, 20., 2007, Vitória. Anais... Vitória: SBF, 2007. p. 25-30, 2008.

MIZOBUTSI, G. P. et al. Efeito da aplicação de cianamida hidrogenada e de óleo mineral em caquizeiro. Revista Brasileira de Fruticultura, v. 25, n. 1, p. 89-92, 2003.

NAKASU, B. H.; RASEIRA, M. C. B. 'Turmalina': uma cultivar de pêssego para uso industrial. Ciência e Agrotecnologia, v. 23, n. 1, p. 234-236, 1999.

OR, E.; VIOZNY, I.; FENNEL, A. Dormancy in grape buds: isolation and characterization of catalase cDNA and analysis of its expression following chemical induction of bud dormancy release. Plant Science, v. 162, n. 1, p. 121-130, 2002.

PEREZ, F. J.; LIRA, W. Possible role of catalase in postdormancy bud break in grapevines. Journal of Plant Physiology, v. 162, n. 3, p. 301-308, 2005.

PÉREZ, S. Yield stability of peach germplasm differing in dormancy and blooming season in the Mexican subtropics. Scientia Horticulturae, v. 100, n. 1/4, p. 15-21, 2004.

PIRES, E. J. P.; MARTINS, F. P. Técnicas de cultivo. In: POMMER, C. V. (Ed.). Uva: tecnologia de produção, pós-colheita, mercado. Porto Alegre: Cinco Continentes, 2003. p. 351-403.

RASEIRA, M. C. B.; NAKASU, B. H. Cultivares: descrição e recomendação. In: MEDEIROS, C. A. B.; RASEIRA, M. do C. B. (Ed.). A cultura do pessegueiro. Brasília: EMBRAPA, SPI; Pelotas: EMBRAPA, CPACT, 1998. p. 29-97.

RASEIRA, M. C. B; NAKASU, B. H.; PEREIRA, J. F. M. Seleções avançadas de pessegueiros produtoras de frutos para mesa. In: CONGRESSO BRASILEIRO DE FRUTICULTURA, 20., 2007, Vitória. Anais... Vitória: SBF, 2007. p. 43, 2007.

TERADA, M. et al. Differential rapid analysis ascorbic acid and ascorbic acid 2-sulfate by dinitrophenilhydrazine method. Anlytical Biochemistry, v. 84, n. 2, p. 604-608, 1979.

TOEBE, M. et al. Dimensionamento amostral para avaliar firmeza de polpa e cor da epiderme em pêssego e maçã. Revista Ciência Agronômica, v. 42, n. 4, p. 1026-1035, 2011.

TREVISAN, R. et al. Atributos de qualidade considerados pelo consumidor de Pelotas - RS, na compra de pêssego in natura. Revista Brasileira Agrociência, v. 12, n. 3, p. 371-374, 2006.

WALTON, E. F. et al. A rapid transcriptional activation is induced by the dormancy-breaking chemical hydrogen cyanamide in Kiwifruti (Actinidia deliciosa) buds. Journal of Experimental Botany, v. 60, n. 13, p. 3835-3848, 2009. 